\title{
Glucocorticoid receptors in human preadipocytes: regional and gender differences
}

\author{
J M Joyner, L J Hutley and D P Cameron \\ Department of Diabetes and Endocrinology, Princess Alexandra Hospital, Woolloongabba, Queensland, Australia \\ (Requests for offprints should be addressed to J Joyner, Department of Diabetes and Endocrinology, Princess Alexandra Hospital, Ipswich Road, \\ Woolloongabba, Queensland, Australia 4102; Email: jjoyner@medicine.pa.uq.edu.au)
}

\begin{abstract}
Glucocorticoid excess causes visceral obesity and its accompanying insulin resistance, dyslipidemia and hypertension. Glucocorticoids enhance preadipocyte (PA) differentiation and increase their aromatase activity (oestrogen production) and there is regional variability in these PA processes. Therefore, we studied human PAs for the presence of, and any regional or gender differences in, glucocorticoid receptors (GRs).

Confluent subcultured human subcutaneous $(\mathrm{Sc})$ and visceral (Vis) PAs from both genders contained GRs as assessed by GR gene expression and specific glucocorticoid (dexamethasone) binding. The dissociation constant was similar to that of other human cells and there was no difference between Sc and Vis sites or between males and females. There was significantly less GR mRNA in Vis PAs compared with Sc PAs in females $(P=0.008)$ but not
\end{abstract}

in males. There was less glucocorticoid binding in Vis compared with Sc PAs in females, measured by maximal binding capacity $(P=0.035)$ or single saturating dose glucocorticoid binding (Bssd) $(P=0 \cdot 019)$. There was no regional difference in specific glucocorticoid binding in males. There was a gender difference with fewer GRs in Vis PAs in females compared with males measured by Bssd $(P=0 \cdot 006)$.

In summary, GRs are present in human PAs. There is a lower GR density in Vis compared with Sc PAs in females, and females have fewer GRs in Vis PAs compared with males. These differences are likely to affect regional aromatase activity and to contribute to the smaller visceral fat mass in females compared with males.

Journal of Endocrinology (2000) 166, 145-152

\section{Introduction}

Glucocorticoid excess predisposes to visceral obesity and its accompanying insulin resistance, dyslipidemia and hypertension. Glucocorticoids regulate multiple processes in adipose tissue influencing fat cell size and adipose tissue metabolism (Björntorp 1991, 1996). Moreover, glucocorticoids promote differentiation of human preadipocytes (PAs) into mature adipocytes, increasing fat cell number (Hauner et al. 1989). Glucocorticoids also increase the aromatase activity in human PAs (Simpson et al. 1981), with this aromatase activity being an important determinant of systemic and local oestrogen concentrations (Folkerd \& James 1983, Siiteri 1987).

These findings, that glucocorticoids directly influence important physiological functions of the PA, suggest that human PAs contain glucocorticoid receptors (GRs). This is supported by a single glucocorticoid binding assay in human PAs (Simpson et al. 1981), and the presence of GR gene expression in the heterogeneous PA-containing stromovascular fraction of human adipose tissue (Pedersen et al. 1996). Human PAs show regional differences in their susceptibility to differentiate (Adams et al. 1997) and in their aromatase activity (Ackerman et al. 1981), suggesting that there may be regional differences in GR complement. Studies in whole adipose tissue show that GRs are present in adipose tissue with regional differences in GR complement between visceral (Vis) and subcutaneous (Sc) sites (Rebuffé-Scrive et al. 1985, 1990, Miller et al. 1987, Pedersen et al. 1994).

We hypothesised that GRs were present in human PAs and that there were differences in the GR complement of Vis and Sc PAs. We aimed to assess human PAs for the presence of classical (type 2) GRs and for regional and gender differences in GR density.

\section{Materials and Methods}

We studied Sc and Vis PAs from both male and female subjects, for GR gene expression using reverse transcription-polymerase chain reaction (RT-PCR), and for specific glucocorticoid binding using a whole cell binding assay. Regional comparisons of Sc and Vis PAs 
Table 1 Clinical characteristics of subjects. Data are expressed as means \pm S.E.M.; ranges in parentheses

\begin{tabular}{|c|c|c|c|}
\hline & Males $(n=10)$ & Females $(n=11)$ & $P$ \\
\hline Age (years) & $\begin{array}{c}60 \pm 3 \\
(46-75)\end{array}$ & $\begin{array}{c}50 \pm 4 \\
(35-74)\end{array}$ & 0.079 \\
\hline Body mass index $\left(\mathrm{kg} / \mathrm{m}^{2}\right)$ & $\begin{array}{l}30 \cdot 0 \pm 2 \cdot 1 \\
(22 \cdot 3-37 \cdot 4)\end{array}$ & $\begin{array}{l}31 \cdot 2 \pm 2 \cdot 1 \\
(22 \cdot 9-45 \cdot 0)\end{array}$ & $0 \cdot 686$ \\
\hline Waist $(\mathrm{cm})$ & $\begin{array}{c}106 \pm 6 \\
(91-114)^{*}\end{array}$ & $\begin{array}{c}100 \pm 6 \\
(67-144)\end{array}$ & $0 \cdot 507$ \\
\hline Waist-hip ratio & $\begin{array}{l}1 \cdot 02 \pm 0.02 \\
(0.96-1 \cdot 09)^{*}\end{array}$ & $\begin{array}{l}0.89 \pm 0.06 \\
(0 \cdot 68-1 \cdot 38)\end{array}$ & $0 \cdot 123$ \\
\hline
\end{tabular}

${ }^{*} n=7$.

from the same individual (paired samples) were made for GR gene expression using semi-quantitative amplification kinetics analysis RT-PCR, and for specific glucocorticoid binding using the whole cell binding assay and single saturating dose glucocorticoid binding.

\section{Subjects/sample preparation}

Paired abdominal Sc and omental (visceral) adipose tissue samples approximately $1 \mathrm{~cm}^{3}$ were collected during elective surgery from 10 males and 11 females, with informed written consent. The Princess Alexandra Hospital Research Ethics Committee approved the protocol. None of the subjects was chronically using glucocorticoids or had any endocrine disorder with the exception of one with treated hypothyroidism receiving adequate thyroxine replacement. The male and female subjects were equally obese, with the female subjects tending to be younger with a lower waist-hip ratio, although none of the differences were statistically significant (Table 1).

Samples were transported to the laboratory in Ringers solution and were processed within $15 \mathrm{~min}$ by collagenase digestion as previously described (Rodbell 1964). The stromovascular fraction was plated into culture flasks (Corning Inc., Cambridge, UK) in Dulbecco's modified Eagle's medium/Hams F-12 1:1 (DMEM/Hams) (ICN Biomedical Australasia Pty Ltd, Seven Hills, Australia) with 10\% fetal bovine serum (Commonwealth Serum Laboratories, Brisbane, Australia) and antibiotics. The cells were grown for 2-3 months and subcultured 3-4 times to obtain a homogeneous cell population of sufficient quantity to study. Paired Sc and Vis PA samples were treated identically, preventing regional differences secondary to in vitro effects. The PAs used for the GR gene expression and glucocorticoid binding studies were confluent but undifferentiated, as serum-containing medium is inhibitory to PA differentiation (Entenmann \& Hauner 1996). Confluent human forearm skin fibroblasts were used as the GR positive control (Bruning et al. 1979).

\section{Confirming the PA phenotype}

The subcultured cells were confirmed to be PAs by their ability to differentiate into mature adipocytes under appropriate culture conditions. Confluent subcultured PAs and skin fibroblasts (as a negative control) were incubated in differentiation medium (Adams et al. 1997), a serumfree medium containing glucocorticoids and insulin, and an activator of peroxisome-proliferator-activated receptor- $\gamma$, BRL 49653 (a kind gift from SmithKlineBeecham, Welwyn, UK). After 14-21 days, the PAs but not the fibroblasts expressed lipoprotein lipase, glycerol-3phosphate dehydrogenase and leptin, as assessed by Northern blot. Furthermore, the PAs, in contrast to the fibroblasts, accumulated significant quantities of lipid as confirmed by oil-red $\mathrm{O}$ staining.

\section{GR gene expression}

Confluent PAs were washed with phosphate-buffered saline (PBS) and the RNA was extracted (Chomczynski \& Sacchi 1987) and stored at $-70{ }^{\circ} \mathrm{C}$ until use. Total RNA was reverse transcribed using the random hexamer priming option of a commercially available kit (SUPERSCRIPT Preamplification System for first strand cDNA synthesis, Life Technologies, Gaithersburg, VA, USA). Glyceraldehyde-3-phosphate dehydrogenase (GAPDH) RT-PCR as a positive RT control, and a minus reverse transcriptase negative control, were included for each RNA sample. Previously published GR and GAPDH primer sequences (Dibattista et al. 1993) were obtained commercially (DNA Express, Fort Collins, USA). The PCR was performed in a Corbett Research PC-90 microplate thermal sequencer and the PCR products visualised under ultraviolet illumination after electrophoresis on an ethidium bromide-labelled 2\% DNA agarose gel.

Dual primer amplification kinetics analysis RT-PCR was used to compare GR gene expression in paired Sc and Vis PAs. The GR gene expression was adjusted for any 


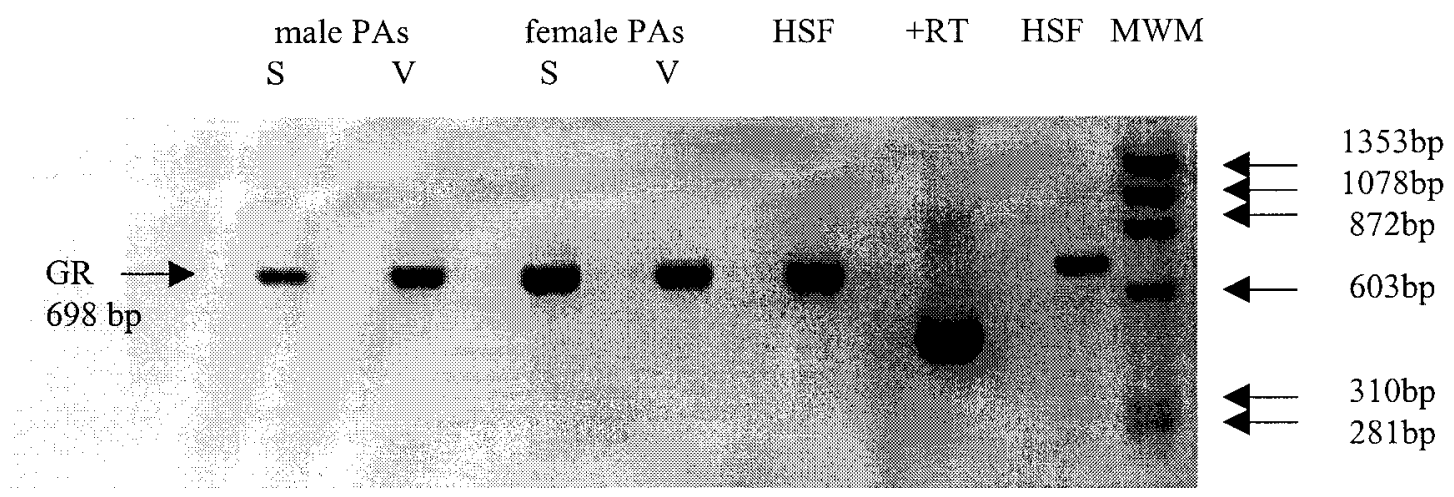

Figure 1 Ethidium bromide-labelled gel of glucocorticoid receptor PCR products, each sample accompanied (on its right) by its minus reverse transcriptase control. bp, base pairs; HSF, human skin fibroblasts; MWM, molecular weight marker; $+\mathrm{RT}$, kit positive reverse transcriptase control; V, visceral; S, subcutaneous.

differences in amount of starting total RNA by adjusting for the expression of GAPDH, giving a result in arbitrary units. Briefly, a 698 base pair sequence of GR cDNA, and a 318 base pair sequence of GAPDH, were co-amplified after an initial 4 PCR cycles with the GR primers only. Aliquots $(10 \mu \mathrm{l})$ were removed at GR cycles 23-36 (GAPDH cycles 19-32). Negatives (Polaroid 665 film) of the electrophoresed PCR products were used for densitometry in a Molecular Dynamics personal densitometer. The GR band density at a cycle number chosen in the log linear range for both samples was adjusted by the GAPDH band density chosen similarly. Paired Sc and Vis samples were always assayed together allowing direct comparison of Sc and Vis paired samples' GR gene expression.

\section{Glucocorticoid binding}

Flasks $\left(25 \mathrm{~cm}^{2}\right)$ of confluent cells were washed with PBS and preincubated in DMEM/Hams for $30 \mathrm{~min}$ at $37^{\circ} \mathrm{C}$. This was followed by a $60-\mathrm{min}$ incubation with one of six serial dilutions of $0 \cdot 78-25 \mathrm{nM}$ tritiated dexamethasone ( $\left[{ }^{3} \mathrm{H}\right]$ Dex) $(70-110 \mathrm{Ci} / \mathrm{mmol}$, Amersham Australia Pty Ltd, Sydney, Australia) or 0.78-25 nM [ $\left.{ }^{3} \mathrm{H}\right]$ Dex with 250 times excess unlabelled dexamethasone (Sigma-Aldrich Pty Ltd, Castle Hill, Australia) in DMEM/Hams. All incubations were carried out in duplicate or triplicate. An aliquot of the prepared $25 \mathrm{nM}\left[{ }^{3} \mathrm{H}\right]$ Dex media was added to scintillation fluid (Instagel Plus, Packard, Meriden, USA) and counted in a Minaxi-Tricarb 4000 series scintillation counter, to allow conversion from disintegrations/ min to moles. An aliquot of the media was removed near the end of the incubation to obtain an accurate measure of unbound $\left[{ }^{3} \mathrm{H}\right]$ Dex in each flask. After washing the cells with ice-cold PBS, the cells were lysed and an aliquot was taken from each flask to count bound $\left[{ }^{3} \mathrm{H}\right] \mathrm{Dex}$, and for protein determination (Bradford 1976). A Scatchard plot provided the binding characteristics for each sample.
Glucocorticoid binding was also assessed using a single $25 \mathrm{nM}$ concentration of $\left[{ }^{3} \mathrm{H}\right]$ Dex with and without 250 times excess unlabelled Dex to obtain specific glucocorticoid binding at a single saturating dose of $\left[{ }^{3} \mathrm{H}\right] \mathrm{Dex}$. The purity of the $\left[{ }^{3} \mathrm{H}\right]$ Dex was regularly checked by thin layer chromatography as per the manufacturer's instructions and was always greater than $95 \%$ at the time of assay.

\section{Statistical analysis}

Vis and Sc PA GR gene expression was compared using the Wilcoxon signed rank test. All other regional comparisons used the Student's paired $t$-test (two-tailed). All gender comparisons used the two-sample $t$-test for means (two-tailed). The Scatchard plots, the two glucocorticoid binding measures comparison, and the comparison of the Vis/Sc PA GR gene expression and the corresponding glucocorticoid binding ratio, were tested for simple linear correlation using Pearson's correlation coefficient applying the appropriate degrees of freedom. The statistical analyses were performed using the data analysis function of Microsoft Excel Version 5 and the SPSS data analysis package version 8 . A result with a $P$ value of less than $0 \cdot 05$ was taken as statistically significant.

\section{Results}

\section{Gene expression}

Human PAs expressed the GR gene as assessed by RT-PCR. A single PCR product band, consistent with the expected 698 base pair product was obtained from all $36 \mathrm{PA}$ samples that were successfully reverse transcribed (Fig. 1). The samples included Sc and Vis PAs from males and females. The same sized band was present in the fibroblast positive controls but not in the minus RT negative controls (Fig. 1). 


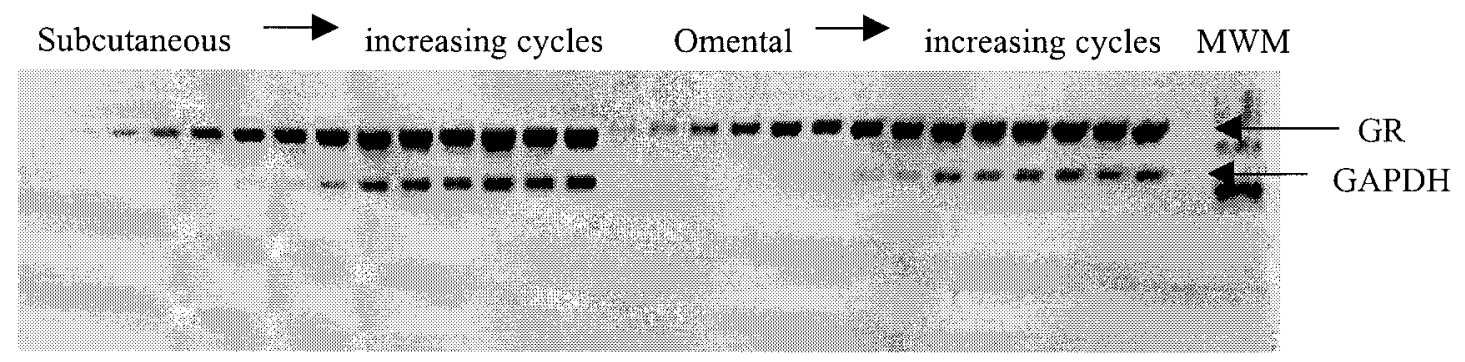

Figure 2 Ethidium bromide-labelled gel of the GR and GAPDH PCR products, over 23-37 and 20-34 cycles respectively, for a paired subcutaneous and visceral (omental) preadipocyte sample. MWM, molecular weight marker.

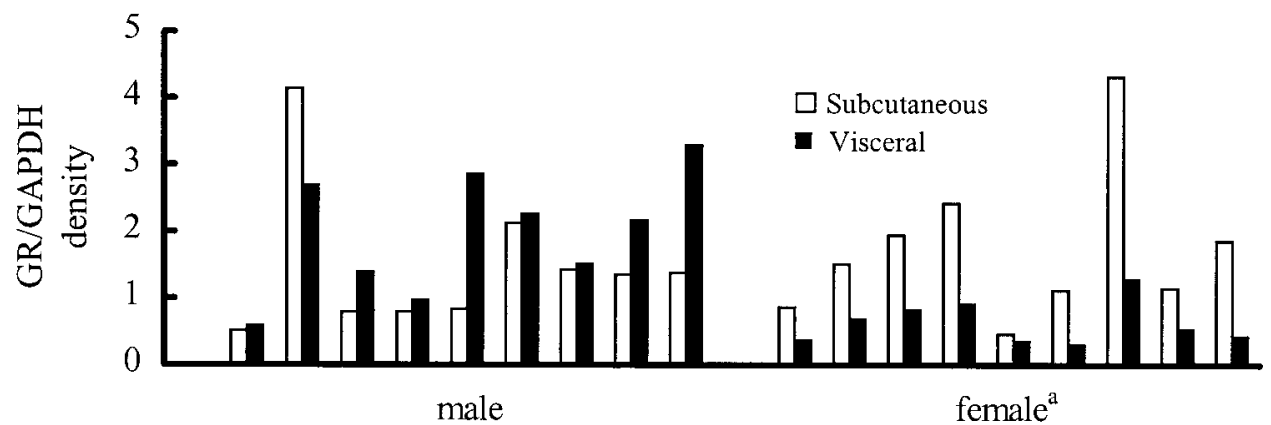

Figure 3 Glucocorticoid receptor gene expression in paired subcutaneous and omental (visceral) preadipocyte samples; ${ }^{a} P=0.008$ for subcutaneous versus visceral preadipocytes in females.

Nine male and nine female paired Sc and Vis PA samples were assessed by dual primer amplification kinetics analysis RT-PCR. The GR and GAPDH PCR products showed an increase in density with increasing cycles before reaching a plateau (Fig. 2). For the female subjects, there was significantly less GR gene expression in Vis PAs compared with Sc PAs $(P=0 \cdot 008)$ with all nine Vis samples showing less GR gene expression than the corresponding Sc samples (Fig. 3). For the male subjects there was no significant difference in GR gene expression between Sc and Vis PAs (Fig. 3) $(P=0 \cdot 066)$. There was no statistical difference in GR gene expression in Sc and Vis PAs for the group as a whole $(P=0 \cdot 327)$.

\section{Glucocorticoid binding}

All 29 PA samples tested showed saturable specific dexamethasone binding (Fig. 4a). This included both male and female, Sc and Vis samples. Linear Scatchard plots were obtained from 27 samples (Fig. 4b). The dissociation constant $\left(K_{\mathrm{d}}\right)$ ranged from $4.67 \mathrm{nM}$ to $24.88 \mathrm{nM}$. The maximal binding capacity (Bmax) ranged from $152 \mathrm{fmol} /$ $\mathrm{mg}$ to $867 \mathrm{fmol} / \mathrm{mg}$. The $K_{\mathrm{d}}$ was comparable to other human cell types known to contain GR assayed by similar methods (Bertovitz et al. 1988, Corrigan et al. 1991, Dibattista et al. 1993). The $K_{\mathrm{d}}$ and Bmax were similar to results for the two forearm fibroblast strains assayed as positive controls $\left(K_{\mathrm{d}}, 6.1 \mathrm{nM}\right.$ and $11.1 \mathrm{nM}$; Bmax, $367 \mathrm{fmol} / \mathrm{mg}$ and $630 \mathrm{fmol} / \mathrm{mg}$ ).
The successful whole cell binding assays included six paired Sc and Vis samples for each gender (Table 2). There was no significant difference in $K_{\mathrm{d}}$ between $\mathrm{Sc}$ and Vis PAs for males $(P=0.90)$, females $(P=0.77)$, or for the group as a whole $(P=0 \cdot 78)$. Comparing the results for males and females, there were no gender differences in $K_{\mathrm{d}}$ for either Sc or Vis PAs $(P=0.21$ and $P=0.21$ respectively). There was a significant difference between the Sc and Vis Bmax in females $(P=0.035)$, with less glucocorticoid binding in Vis PAs, but there was no regional difference in males $(P=0 \cdot 34)$. There was lower Bmax for Vis PAs compared with Sc PAs for the group as a whole $(P=0.023)$. Comparing the results for males and females, there were no gender differences in $\mathrm{Sc}$ or Vis $\mathrm{Bmax}$ ( $P=0.89$ and $P=0.45$ respectively).

Ten male and eleven female paired samples were assessed for specific dexamethasone binding using the single saturating dose binding method (Bssd) (Table 3). There was a significantly lower Bssd in Vis compared with Sc PAs in females $(P=0 \cdot 019)$ but not in males $(P=0 \cdot 78)$. There was no significant difference in Bssd between paired Sc and Vis PA samples in the group as a whole $(P=0 \cdot 19)$. Comparing the results for males and females, females had less glucocorticoid binding in Vis PAs $(P=0.006)$ with no gender difference for Sc PAs $(P=0 \cdot 114)$.

There was a strong simple linear correlation between the two methods of ascertaining specific glucocorticoid binding, the Bmax and the Bssd $(n=24, P<0 \cdot 001)$. This 
(a)

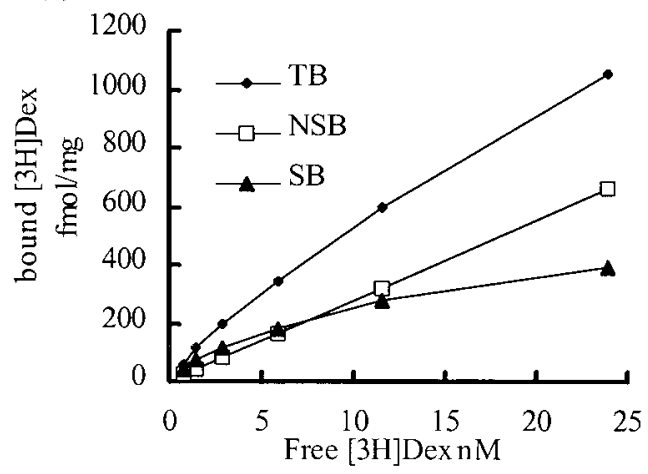

(b)

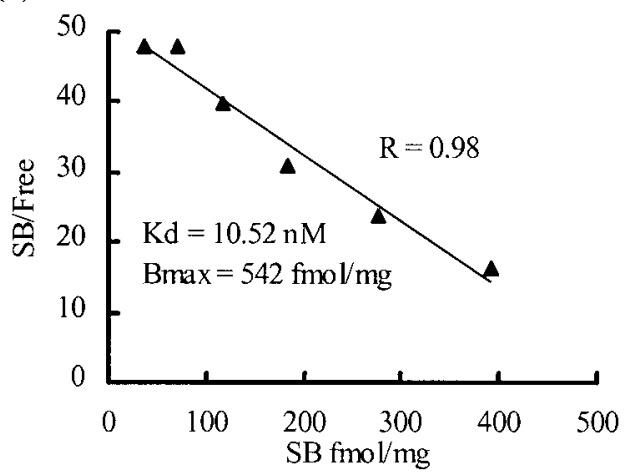

Figure 4 Glucocorticoid binding in human preadipocytes. (a) Graph of $\left[{ }^{3} \mathrm{H}\right]$ Dex binding in human PAs showing total binding (TB), nonspecific binding (NSB) and saturable specific binding (SB). (b) Corresponding Scatchard analysis. R, Pearson correlation coefficient.

confirmed that the single saturating dose binding method was appropriate for assessing specific glucocorticoid binding in a whole cell system in PAs, as has been shown for androgen binding in cultured fibroblasts using similar

Table 2 Paired subcutaneous and visceral preadipocytes, dexamethasone binding assays. Results are expressed as the mean \pm S.E.M.

\begin{tabular}{|c|c|c|}
\hline & $\boldsymbol{k}_{\mathbf{d}}(\mathrm{nM})$ & B $\max (\mathrm{fmol} / \mathrm{mg})$ \\
\hline \multicolumn{3}{|l|}{ Samples } \\
\hline \multicolumn{3}{|l|}{ Male $(n=6)$} \\
\hline Subcutaneous & $9 \cdot 3 \pm 1 \cdot 2$ & $465 \pm 47$ \\
\hline Viceral & $9 \cdot 2 \pm 1 \cdot 7$ & $413 \pm 88$ \\
\hline \multicolumn{3}{|l|}{ Female $(n=6)$} \\
\hline Subcutaneous & $12 \cdot 7 \pm 2 \cdot 2$ & $455 \pm 43^{*}$ \\
\hline Viceral & $13 \cdot 5 \pm 2 \cdot 8$ & $327 \pm 63^{*}$ \\
\hline \multicolumn{3}{|l|}{ Both $(n=12)$} \\
\hline Subcutaneous & $11 \cdot 0 \pm 1 \cdot 3$ & $460 \pm 31^{* *}$ \\
\hline Viceral & $11 \cdot 4 \pm 1 \cdot 7$ & $370 \pm 53^{* *}$ \\
\hline
\end{tabular}

${ }^{*} P=0 \cdot 035 ;{ }^{* *} P=0 \cdot 023$.

Table 3 Paired subcutaneous and visceral preadipocytes, dexamethasone single saturating dose binding results expressed as the mean \pm S.E.M.

\begin{tabular}{ll} 
& Bssd $(\mathrm{fmol} / \mathrm{mg})$ \\
\cline { 2 - 2 } $\begin{array}{l}\text { Samples } \\
\text { Male }(n=10)\end{array}$ \\
$\quad \begin{array}{l}\text { Subcutaneous } \\
\text { Viceral }\end{array}$ & $310 \pm 26$ \\
Female $(n=11)$ & $320 \pm 41^{* *}$ \\
$\quad$ Subcutaneous & $240 \pm 33^{*}$ \\
$\quad$ Viceral & $171 \pm 28^{*, * *}$ \\
Both $(n=21)$ & \\
$\quad$ Subcutaneous & $273 \pm 22$ \\
Viceral & $244 \pm 29$
\end{tabular}

${ }^{*} P=0 \cdot 019 ;{ }^{* *} P=0 \cdot 006$. methods (Kaufman et al. 1983). There was also a strong linear correlation between the relative Vis/Sc GR gene expression and the corresponding Vis/Sc glucocorticoid binding ratio $(n=16, P=0 \cdot 001)$.

\section{Discussion}

In this paper we have shown that cultured human undifferentiated PAs contain the classical GR. In females, there was significantly less GR gene expression and glucocorticoid binding in Vis compared with Sc PAs. In contrast, in males there was no regional difference in GR complement.

Despite the subculturing and prolonged in vitro growth, the cells studied retained their PA phenotype with the ability to differentiate into mature adipocytes, including expressing leptin that is adipocyte-specific, under appropriate culture conditions (Adams et al. 1997). This strongly suggests that the regional and gender differences in GR complement are true characteristics of the PA. Moreover, their presence after prolonged in vitro growth suggests that these are intrinsic differences, rather than differences due to circulating hormones or differing regional influences. The potential stability of the steroid receptor complement of subcultured cells is exemplified by the consistent regional differences in androgen receptor density and androgen responsiveness of subcultured skin fibroblasts (Brown \& Migeon 1981).

The concordance of GR gene expression and specific glucocorticoid binding agrees with previous studies showing that GR number parallels GR mRNA at steady state in a number of systems (Northrop et al. 1986, Dibattista et al. 1993, Brönnegard et al. 1995). It suggests that in confluent PAs, GR density is regulated at the level of gene transcription.

The gender differences in Vis PA GR complement may contribute to the gender differences in regional fat 
deposition (Lemieux et al. 1993). This is supported by observations that even when circulating sex steroid levels are extremely low, gender differences in adiposity are still apparent. There are gender differences in degree of body fat in prepubertal children, with girls having more fat than boys (Taylor et al. 1997). Moreover, there are differences in body fat distribution, with pre-pubertal males having relatively more intra-abdominal fat and less subcutaneous abdominal fat than pre-pubertal females, sufficient to contribute to gender differences in leptin levels (Nagy et al. 1997).

The regional differences in GR density found in our study are consistent with, and may explain, the sitespecific differences in PA aromatase activity in females. Aromatase activity in PAs is stimulated by glucocorticoids (Mendelson et al. 1987), with evidence that this is a direct effect mediated by GRs (Simpson et al. 1981). It has been shown that there are regional differences in aromatase expression in confluent cultured PAs from female subjects, with Vis PAs having less aromatase activity than Sc PAs (Ackerman et al. 1981). This is likely to be biologically important as PAs are the main cell type in adipose tissue responsible for it's aromatase activity (Ackerman et al. 1981). Adipose tissue is a major site for the aromatisation of androgens to oestrogens, influencing both systemic oestrogen concentrations and the paracrine effects of steroid hormones in adipose tissue (Folkerd \& James 1983, Siiteri 1987, Labrie 1991).

It is not clear if regional differences in GR complement cause regional differences in PA differentiation. Glucocorticoids increase PA differentiation (Hauner et al. 1989) and there are regional differences in susceptibility to differentiation of human PAs in vitro, with Sc PAs differentiating more readily than Vis PAs, but this was true for both genders (Adams et al. 1997). However, these studies were performed at supraphysiological glucocorticoid concentrations, possibly obscuring any potential differences dependent on GR complement.

The gender dimorphism in GR distribution was an unexpected but robust finding, occurring both at the level of gene expression and glucocorticoid binding. Gender dimorphism is also seen in adipose tissue lipoprotein lipase levels (Rebuffé-Scrive et al. 1989, Fried et al. 1993) and leptin expression (Montague et al. 1997) with less leptin and lipoprotein lipase in Vis sites compared with $\mathrm{Sc}$ sites in females, with a smaller or absent regional difference in males. No direct relationship between the GR complement of PAs and these two products of mature adipocytes, leptin and lipoprotein lipase, can be concluded. However, it is interesting that both leptin and lipoprotein lipase are regulated by glucocorticoids (Fried et al. 1993, Russell et al. 1998) and show a pattern of expression similar to the GR expression in human PAs. There are other examples of a gender dimorphism in steroid hormone receptor complement. In gonadectomised and adrenalectomised rats, there was no progesterone receptor expression in adipose tissue in genetic males while it was present in adipose tissue in females (Gray \& Wade 1980). It is hypothesised that the in utero exposure to sex steroids that results in sexual determination includes this effect on receptor expression.

This is the first study to compare GR numbers in Vis and Sc human PAs. The pattern of GR density found in this study of PAs is different to the results found in whole adipose tissue, where Vis adipose tissue was shown to have a greater number of GR binding sites than Sc adipose tissue with no gender differences (Rebuffé-Scrive et al. 1985, 1990, Miller et al. 1987, Pedersen et al. 1994). A gender difference in regional GR complement between two Sc adipose tissue depots, Sc abdominal and gluteal adipose tissue, has been reported however (Brönnegard et al. 1990), and supports the general concept of a gender dimorphism in the regional GR complement of human adipose tissue.

There are a number of possible explanations for the disparity in the regional GR complement in PAs and whole adipose tissue. GR expression may vary between PAs and adipocytes as has been shown in porcine adipose tissue (Chen et al. 1995). There are regional differences in the adipocyte size (Rebuffe-Scrive et al. 1989) and the cellular composition of whole adipose tissue (Rink et al. 1996) that are likely to affect the measured GR density of whole adipose tissue homogenates. In general, Vis adipocytes are smaller than $\mathrm{Sc}$ adipocytes from the same individual (Sjöström et al. 1972) and a site-specific difference in GR complement in one paper was abolished when the data was expressed per adipocyte (Rebuffé-Scrive et al. 1985). In addition, the differing internal milieu of whole adipose tissue from different sites may affect GR expression in tissue explants.

The GR complement of PAs is critical to the response of PAs to glucocorticoids but it is only one aspect of the complex interaction of glucocorticoids with adipose tissue. In vivo, glucocorticoids increase Vis adipose tissue at the expense of peripheral Sc tissue (Björntorp 1996). This is likely to be due, in part, to the higher density of GRs in Vis compared with Sc whole adipose tissue, as discussed above. Differences in the local glucocorticoid concentrations are also likely to contribute, with $11 \beta$ hydroxysteroid dehydrogenase type 1 , that catalyses inactive cortisone to active cortisol, being present in human PAs with greater activity in Vis compared with Sc PAs (Bujalska et al. 1997, 1999).

In conclusion, human PAs contain classical GRs. Females have fewer GRs in Vis PAs compared with Sc PAs, and in comparison with males. This lower GR density in Vis PAs in women is likely to be physiologically relevant, contributing to the regional differences in aromatase activity in females and the smaller intraabdominal fat mass relative to total body fat in females compared with males. 


\section{Acknowledgements}

J M J was the recipient of The Brisbane Teaching Hospitals Scholarship in 1995, and the NH\&MRC Medical Postgraduate Research Scholarship 1996/1997. This research received financial support from the Diabetes Australia Research Grants Programme and The Princess Alexandra Hospital Research and Development Foundation. Special thanks to the volunteers and their surgeons at the Princess Alexandra Hospital for providing the tissue for study.

\section{References}

Ackerman GE, Smith ME, Mendelson CR, MacDonald PC \& Simpson ER 1981 Aromatization of androstenedione by human adipose tissue stromal cells in monolayer culture. Journal of Clinical Endocrinology and Metabolism 53 412-417.

Adams M, Montague CT, Prins JB, Holder JC, Smith SA, Sanders L, Sewter CP, Digby JE, Lazar MA, Chatterjee VKK \& O'Rahilly S 1997 Activators of PPAR $\gamma$ have depot-specific effects on human preadipocyte differentiation. Journal of Clinical Investigation $\mathbf{1 0 0}$ 3149-3153.

Bertovitz GD, Carter KA, Migeon CJ \& Brown TR 1988 Downregulation of the glucocorticoid receptor by dexamethasone in cultured human skin fibroblasts: implications for the regulation of aromatase activity. Journal of Clinical Endocrinology and Metabolism 66 1029-1036.

Björntorp P 1991 Metabolic implications of body fat distribution. Diabetes Care 14 1132-1143.

Björntorp P 1996 The regulation of adipose tissue distribution in humans. International Journal of Obesity 20 291-302.

Bradford MM 1976 A rapid and sensitive method for the quantitation of microgram quantities of protein utilizing the principle of proteindye binding. Analytical Biochemistry 72 248-254.

Brönnegard M, Arner P, Hellström L \& Gustafsson JA 1990 Glucocorticoid receptor messenger ribonucleic acid in different regions of human adipose tissue. Endocrinology 127 1689-1696.

Brönnegard M, Reynisdottir S, Marcus C, Stierna P \& Arner P 1995 Effect of glucocorticoid treatment on glucocorticoid receptor expression in human adipocytes. Journal of Clinical Endocrinology and Metabolism 80 3608-3612.

Brown TR \& Migeon CJ 1981 Cultured human skin fibroblasts: a model for the study of androgen action. Molecular and Cellular Biochemistry 36 3-22.

Bruning PF, Meyer WJ \& Migeon CJ 1979 Glucocorticoid receptor in cultured human skin fibroblasts. Journal of Steroid Biochemistry 10 587-593.

Bujalska IJ, Kumar S \& Stewart PM 1997 Does central obesity reflect 'Cushing's disease of the omentum'? Lancet 349 1210-1213.

Bujalska IJ, Kumar S, Hewison M \& Stewart PM 1999 Differentiation of adipose stromal cells: the roles of glucocorticoids and 11 $\beta$-hydroxysteroid dehydrogenase. Endocrinology 140 3188-3196.

Chen NX, White BD \& Hausman GJ 1995 Glucocorticoid receptor binding in porcine preadipocytes during development. Journal of Animal Science 73 722-727.

Chomczynski P \& Sacchi N 1987 Single-step method of RNA isolation by acid guanidinium thiocynanate-phenol-chloroform extraction. Analytical Biochemistry 162 156-159.

Corrigan CJ, Brown PH, Barnes NC, Szefler SJ, Tsai J-J, Frew AJ \& Kay AB 1991 Glucocorticoid resistance in chronic asthma. American Review of Respiratory Disease 144 1016-1025.

Dibattista JA, Martel-Pelletier J, Antakly T, Tardif G, Cloutier J-M \& Pelletier J-P 1993 Reduced expression of glucocorticoid receptor levels in human osteoarthritic chondrocytes. Role in the suppression of metalloprotease synthesis. Journal of Clinical Endocrinology and Metabolism 76 1128-1134.

Entenmann G \& Hauner H 1996 Relationship between replication and differentiation in cultured human adipocyte precursor cells. American Journal of Physiology 270 C1011-C1016.

Folkerd EJ \& James VHT 1983 Aromatization of steroids in peripheral tissues. Journal of Steroid Biochemistry 19 687-690.

Fried SK, Russell CD, Grauso NL \& Brolin RE 1993 Lipoprotein lipase regulation by insulin and glucocorticoid in subcutaneous and omental adipose tissues of obese women and men. Journal of Clinical Investigation 92 2191-2198.

Gray JM \& Wade GN 1980 Cytoplasmic estrogen, but not progestin, binding sites in male rat adipose tissues. American Journal of Physiology 239 E237-E241.

Hauner H, Entenmann G, Wabitsch M, Gaillard D \& Ailhaud G 1989 Promoting effect of glucocorticoids on the differentiation of human adipocyte precursor cells cultured in a chemically defined medium. Journal of Clinical Investigation 84 1663-1670.

Kaufman M, Pinsky L, Hollander R \& Bailey JD 1983 Regulation of the androgen receptor by androgen in normal and androgenresistant genital skin fibroblasts. Journal of Steroid Biochemistry 18 383-390.

Labrie F 1991 At the cutting edge. Intracrinology. Molecular and Cellular Endocrinology 78 C113-C118.

Lemieux S, Prud'homme D, Bouchard C, Tremblay A \& Després J-P 1993 Sex differences in the relation of visceral adipose tissue accumulation to total body fatness. American Journal of Clinical Nutrition $\mathbf{5 8}$ 463-467.

Mendelson CR, Evans CT \& Simpson ER 1987 Regulation of aromatase in estrogen-producing cells. Journal of Steroid Biochemistry 27 753-757.

Miller LK, Kral JG, Strain GW \& Zumoff B 1987 Differential binding of dexamethasone to ammonium sulfate precipitates of human adipose tissue cytosols. Steroids 49 507-522.

Montague CT, Prins JB, Sanders L, Digby JE \& O'Rahilly S 1997 Depot- and sex-specific differences in human leptin mRNA expression. Diabetes 46 342-347.

Nagy TR, Gower BA, Trowbridge CA, Dezenberg C, Shewchuk RM \& Goran MI 1997 Effects of gender, ethnicity, body composition, and fat distribution on serum leptin concentrations in children. Journal of Clinical Endocrinology and Metabolism 82 2148-2152.

Northrop JP, Danielsen M \& Ringold GM 1986 Analysis of glucocorticoid unresponsive cell variants using a mouse glucocorticoid receptor complementary DNA clone. Journal of Biological Chemistry 261 11064-11070.

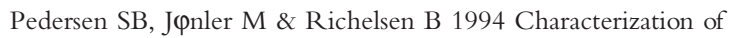
regional and gender differences in glucocorticoid receptors and lipoprotein lipase activity in human adipose tissue. Journal of Clinical Endocrinology and Metabolism 78 1354-1359.

Pedersen SB, Fuglsig S, Sjøgren P \& Richelsen B 1996 Identification of steroid receptors in human adipose tissue. European Journal of Clinical Investigation 26 1051-1056.

Rebuffé-Scrive M, Lundholm K \& Björntorp P 1985 Glucocorticoid binding to human adipose tissue. European Journal of Clinical Investigation 15 267-271.

Rebuffé-Scrive M, Andersson B, Olbe L \& Björntorp P 1989 Metabolism of adipose tissue in intra-abdominal depots of nonobese men and women. Metabolism 38 453-458.

Rebuffé-Scrive M, Brönnegard M, Nilsson A, Eldh J, Gustafsson J-A \& Björntorp P 1990 Steroid hormone receptors in human adipose tissues. Journal of Clinical Endocrinology and Metabolism 71 1215-1219.

Rink JD, Simpson ER, Barnard JJ \& Bulun SE 1996 Cellular characterization of adipose tissue from various body sites of women. Journal of Clinical Endocrinology and Metabolism 81 2443-2447.

Rodbell M 1964 Metabolism of isolated fat cells. Journal of Biological Chemistry 239 375-380. 
Russell CD, Petersen RN, Rao SP, Ricci MR, Prasad A, Zhang Y, Brolin RE \& Fried SK 1998 Leptin expression in adipose tissue from obese humans: depot-specific regulation by insulin and dexamethasone. American Journal of Physiology 275 E507E515.

Siiteri PK 1987 Adipose tissue as a source of hormones. American Journal of Clinical Nutrition 45 277-282.

Simpson ER, Ackerman GE, Smith ME \& Mendelson CR 1981 Estrogen formation in stromal cells of adipose tissue of women: induction by glucocorticosteroids. PNAS 78 5690-5694.
Sjöström L, Smith U, Krotkiewski M \& Björntorp P 1972 Cellularity in different regions of adipose tissue in young men and women. Metabolism 21 1143-1153.

Taylor RW, Gold E, Manning P \& Goulding A 1997 Gender differences in body fat content are present well before puberty. International Journal of Obesity 21 1082-1084.

Received 24 December 1999

Accepted 9 March 2000 